\title{
Faunal Biodiversity Research in the Republic of Georgia: A Short Review of Trends, Gaps, and Needs in the Caucasus Biodiversity Hotspot
}

\section{Levan Mumladze ${ }^{1 *}$ Bella Japoshvili ${ }^{1}$ and Elizabeth P. Anderson ${ }^{3}$}

1 Institute of Zoology and Center of Biodiversity Studies, Institute of Ecology, Ilia State University, Cholokashvili ave.3/5, 0169 Tbilisi, Georgia

2 Department of Earth and Environment, Florida International University, Miami, FL 33199 USA

* Correspondence: lmumladze@ gmail.com; +995 55515861; https://orcid.org/0000-0002-2172-6973

\begin{abstract}
We evaluated progress towards animal biodiversity research in Georgia, a key area in the Caucasus biodiversity hotspot. By reviewing recently (1990-2018) published articles in all areas of animal diversity research, we unmasked the trends in biodiversity inventory, ecological and biogeographical studies, and conservation issues in Georgia. We concluded that species inventory and biodiversity research in Georgia has significantly increased during the last ten years, however the rate and extent of investigation is far from satisfactory. Major gaps remain in all branches of animal diversity research in Georgia, and consequently existing knowledge is inadequate to address modern challenges related to species and ecosystem conservation. We urge local governmental authorities and international scientific societies to support development of stronger research facilities and cultivate interest in biodiversity inventory and research in Georgia as an important step towards maintaining globally important biodiversity in the Caucasus.
\end{abstract}

Keywords: Caucasus hot-spot; Georgia; animal biodiversity; bibliometry

\section{Introduction}

Biodiversity is a broad concept that refers to natural variation across all levels life, important both scientifically but also with the potential to capture human interest (Arbeláez-Cortés 2013). Neither biodiversity itself, nor the study of it, are evenly distributed across the Earth. Concepts like "biodiversity hotspots" have been proposed as ways to identify areas of extraordinary biodiversity and extraordinary threat, and then target them for research and conservation activity (Myers et al. 2000; Mittermeier et al. 2011). Myers et al (2000) identified 25 biodiversity hotspots - later increased to 35 (CEPF 2018) - most of them concentrated in the world's tropical regions. Nevertheless, the list of hotspots also includes a few regions in temperate zone, such as biodiversity hotspots in the Caucasus ecoregion of southeastern Europe.

The Caucasus ecoregion extends over the territories of six countries (Georgia, Azerbaijan, Armenia, Russia, Turkey and Iran), four of which were a part of the former Soviet Union (Georgia, Azerbaijan, Armenia, Russia). The Caucasus biodiversity hotspot's designation was based on an estimated 6300 plant species (1600 endemic) and 632 vertebrate species (59 endemic) occurring over an original extent of $500,000 \mathrm{~km}^{2}$ of primary vegetation (Myers et al. 2000). Compared with other biodiversity hotspots, the Caucasus has supposedly received comparatively less scientific study and potentially less widespread recognition, mainly due to a tenuous political situation in the last few decades. Consequently, biodiversity knowledge remains generally limited and receives limited research (NBISAP 2014).

In the Caucasus region and elsewhere, knowledge of local and regional biodiversity is an essential tool for wildlife conservation and sustainable development (Stork 1994; Humphries et al. 1995; Kotze and Samways 1999; 
Cardoso et al. 2011; Schmeller et al. 2015). Furthermore, having good knowledge of a region's biodiversity can benefit science (for example Fleishman et al. 2002) and the local economy (Edwards and Abivardi 1998). Accordingly, evaluation of the current level of biodiversity knowledge and research trends can significantly help in advancing research priorities and conservation strategies.

In this article, we examine historical and modern trends in faunal biodiversity research in one country within the Caucasus biodiversity hotspot - the Republic of Georgia. Although biodiversity research and conservation has been declared a priority of the Georgian government since 1994 (after signing the Convention on Biological Diversity), the natural history of Georgia still remains understudied. We present a first attempt to summarize the research trends and state of knowledge on Georgia's faunal diversity based on review of literature derived from multiple sources. We also qualitatively evaluated differences in knowledge accumulation between the historical Soviet period and modern Georgia (after independence in 1990 to present). Based on bibliometric analyses, we aimed to answer the following questions: How has intensity of animal biodiversity research varied over time? Which taxa have been most actively studied? How complete is our understanding of total animal diversity and taxon-specific diversity of Georgia? How has research effort been distributed between local and foreign researchers? And, what are the main challenges for animal biodiversity research in Georgia? Based on our own experiences, we also discuss how biodiversity research has helped to motivate conservation projects in Georgia. Finally, we offer suggestions for enhancing biodiversity research and conservation in the country.

\section{The Republic of Georgia (Sakartvelo): An Overview}

Georgia, the center of the Caucasus biodiversity hotspot, encompasses a geographically diverse landscape inhabited by a diverse Tertiary relic flora and fauna with a high degree of endemism (Fig. 1). The Great Caucasus mountain chain forms northern boundary between Georgia and the Russian Federation, while the Lesser Caucasus range runs along the country's southern borders with Turkey and Armenia. Elevation gradients spanning from 0 to $>5200$ meters above sea level and a temperate to subtropical climate have created a wealth of habitats in Georgia, among which forested landscapes (large part of the forest still primeval) cover up to $40 \%$ of the country. Within the $69,500 \mathrm{~km}^{2}$ of national territory, habitats range from humid temperate forest (4000 mm annual precipitation) in the southwest (Colchis), to semi-desert ( $<150 \mathrm{~mm}$ annual precipitation) in the southeast, to alpine meadows and permanent snow in the northern Caucasus mountains to the huge lowland peat-bog swamps at sea level near the Black Sea coastline. 
Georgia was one of the 16 countries comprising the former Soviet Union. The Soviet period was characterized by heavy industrial development in all the south Caucasian countries (Davtyan 2014). Though currently not quantifiable since pre-industrial data are not available, this development supposedly had a significant effect on the natural environment. After dissolution of Soviet Union in 1989, Georgia experienced heavy anthropogenic pressure on its environment, including 15 years of intensive and totally unregulated logging, poaching, and pollution. Since 1989, there also were several military conflicts that resulted in hundreds of square kilometers of burned forest, and the Russian occupation of almost a quarter of the country in the regions of Abkhazia and South Ossetia (Fig. 1), where natural resource exploitation remains uncontrolled even today.

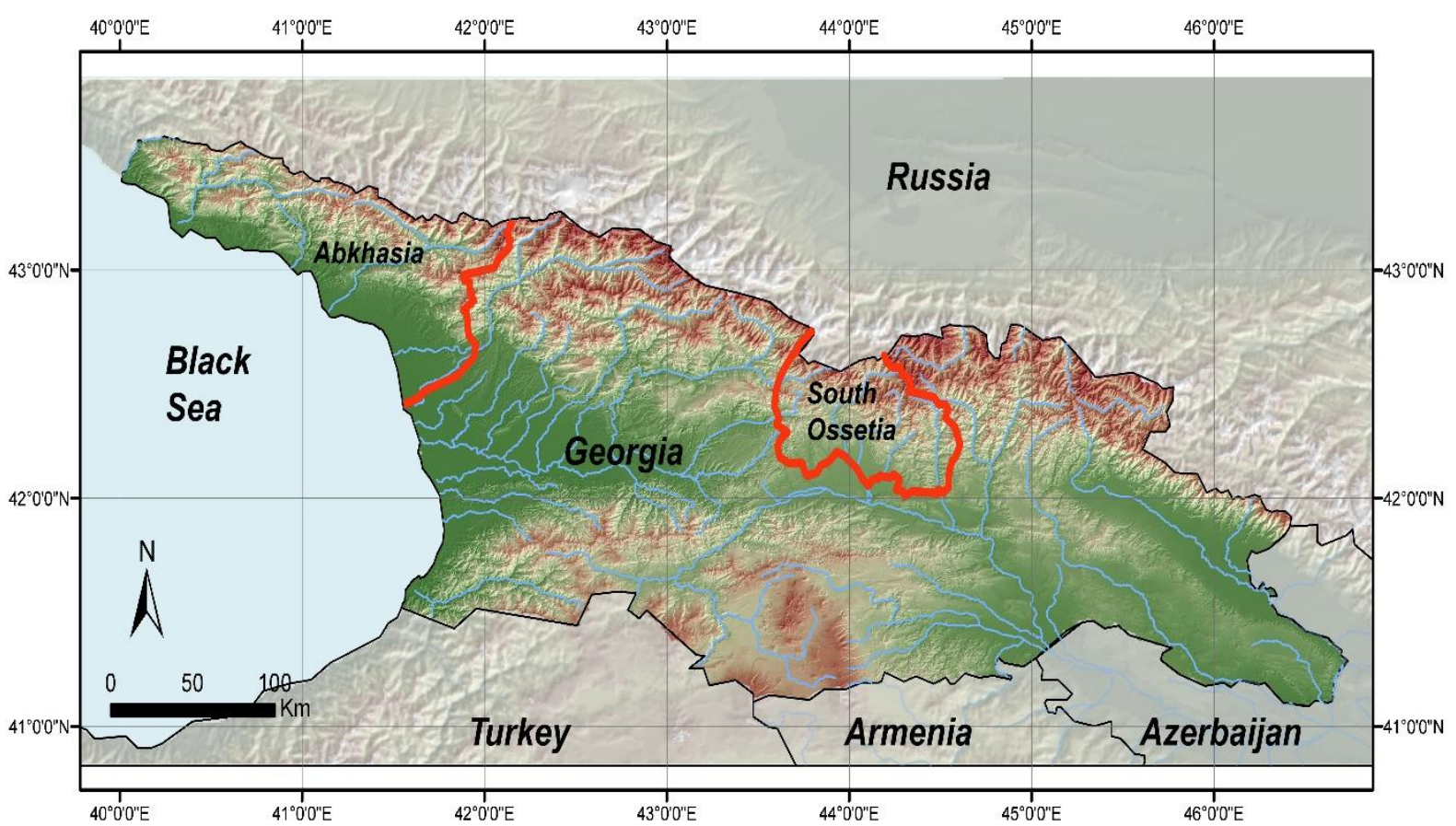

Figure 1. Map of Georgia (Sakartvelo) depicting general landscape structure and main river systems. Red lines represent an occupation border.

\section{Methods}

A comprehensive bibliography for faunal biodiversity studies in pre-modern Georgia (i.e. before 1990) is extremely difficult to collate. Part of the challenge is that the overwhelming majority of the research done in Georgia in the $20^{\text {th }}$ century was published in Georgian or Russian language journals. Today, most of those articles and books are in better cases in print formats with limited copies, and widely unavailable digitally (see for example Japoshvili et al. 2016a). Because of similar limitations to access, many taxonomic works of this time are also frequently overlooked during modern studies and bibliographic analyses.

Nevertheless, although relatively unknown to the international scientific community, the pre-modern period in Georgia was actually one of high scientific productivity for animal biodiversity research. For instance, Georgia had more than 200 zoologists working in academic institutions as of the late 1980s. Scientist at this time were actively collecting materials great deal of which were sent to Russian Museums and elsewhere. As a result, large amount of taxonomic works usually directed by Russian scientists were published in Russian language and to lesser extent in Georgian language journals. Furthermore, a number of papers are still appearing regularly based on old preserved material kept outside Georgia (see for instance Hausdorf (2001) and Evsyukov et al. (2016)). 
Later on, much of the pre-modern work as well as data directly derived from museum collections was included in multi-authored series of books such as "Keys to Animals in the Fauna of the USSR" ("Фауна CCCP” in Russian, published by the Zoological Institute of the Academy of Sciences of Russia). This series began publishing in 1911 and continues today, with 160 volumes available (https://www.zin.ru/publ_r.htm). However, in the way that faunal biodiversity research was included in these series, it is difficult to downscale to Georgia. In most of premodern literature, including this series, there is usually only very general information on species occurrence-for example, that a species is known from Transcaucasia or, in better cases, from Georgia, or from the Georgian Black Sea coast, or mixed forest in Transcaucasia. Even type localities of most of the species described from Georgia during the Soviet period are difficult to geo-reference today. Accordingly, a comprehensive bibliometric analysis of faunal biodiversity research produced during the Soviet period would be an extremely challenging undertaking and not the scope of our work here.

We used multiple approaches to compile a dataset of articles about Georgian faunal biodiversity published after 1990. First, we searched the Web of Science of Clarivate Analytics@ (WoS) and the Scopus database. We executed searches using complex queries in both databases in order to retrieve thematic articles in a field of animal biodiversity sciences (Scopus query: “(SUBJAREA (agri) AND SUBJAREA (bioc) AND TITLE-ABS-KEYAUTH (Georgia) AND NOT TITLE-ABS-KEY (USA) AND NOT TITLE-ABS-KEY ("South Georgia") AND NOT AFFIL ("South Georgia")"; WoS query: “(SU=(BIODIVERSITY CONSERVATION) OR $\mathrm{SU}=(\mathrm{ZOOLOGY})$ OR SU= (ECOLOGY)) AND TS=Georgia NOT (CU=USA OR CU="South Georgia")". However, search results were always overestimated and confounded with studies related to the U.S. state of Georgia. We found no way to effectively separate materials sourced from these two regions without review and separation of individual articles. In our final search, we retrieved 1580 articles from WoS and 521 from Scopus as of 27 December 2018. Subsequently, the title and, if needed, abstract or full text were checked for each entry to filter out studies related to U.S. state of Georgia, plant sciences, or any other subject unrelated to faunal biodiversity. After filtering out all irrelevant content, 325 articles were retrieved from WoS/Scopus databases and used in our analyses. We refer to these as "indexed" articles in this paper. Moreover, there are a number of articles in currently indexed journals published before the inclusion of the journal in the WoS and Scopus were omitted from our retrieved lists. Therefore, we conducted additional searches on the web pages of six journals (Table 1). To the best of our knowledge, these were the journals where articles related to Georgian faunal biodiversity were regularly published in the past. In a few cases (for instance journal "Entomological Review") not all the articles were available on the journal's web page. In such cases, we conducted an accompanying Google Scholar search using the advanced search option and indicating journal name in "return articles published in" field and the needed time period (1996-2006) in "return articles dated between" field.

There are other sources of biodiversity information never indexed in large databases like WoS or Scopus. In particular, some regional English language journals, such as the "Caucasian Entomological Bulletin”, or journals published in Georgian or Russian language, are not typically included in international databases although they contain articles with a substantial part of primary biodiversity data from Georgia, such as taxonomic descriptions and inventory data. Usually such journals/articles do not have recognized peer-review processes. To not miss information provided there, we also screened all the issues published after 1990 in an additional six non-indexed journals (Table 1). These articles are referred to as "non-indexed" in this paper. As the last step, we searched personal web pages, Google Scholar and ResearchGate profiles for all authors (161 authors) having more than 2 
articles (Online Resource T1) in above constructed database to supplement possible missing non-indexed articles.

Table 1. List of Journals, contents of all volumes or part only of which were checked additionally due to unavailability in a Scopus/Web of Science databases.

\begin{tabular}{|c|c|c|}
\hline Journal Title & Scopus Indexing history & Web Address \\
\hline Entomological Review & $\begin{array}{l}\text { between } 1990-1996 \text { and } \\
\text { after } 2011\end{array}$ & https://link.springer.com/journal/volumesAndIssues/11474 \\
\hline Turkish Journal of Zoology & since 1994 & http://journals.tubitak.gov.tr/zoology/index.htm \\
\hline Vestnik Zoologii & since 2009 & http://www.v-zool.kiev.ua/index_e.htm \\
\hline $\begin{array}{l}\text { Bulletin of the Georgian Academy of } \\
\text { Sciences }\end{array}$ & since 2011 & $\begin{array}{l}\text { http://science.org.ge/bulletin/bulletin_contents.html } \\
\text { and } \\
\text { http://science.org.ge/moambe/moambe-g.html }\end{array}$ \\
\hline Arthropoda selecta & since 2011 & http://kmkjournals.com/journals/AS/AS_Index_Volumes \\
\hline Zoosystematica Rossica & since 2014 & https://www.zin.ru/journals/zsr/ \\
\hline Annales of Agrarian Sciences & - & $\begin{array}{l}\text { https://www.journals.elsevier.com/annls-of-agrarian- } \\
\text { science } \\
\text { and } \\
\text { http://openjournals.gela.org.ge/index.php?journal=AGR_SCI } \\
\text { page=index }\end{array}$ \\
\hline $\begin{array}{l}\text { Black Sea - Mediterranean } \\
\text { Environment }\end{array}$ & - & http://www.blackmeditjournal.org/ \\
\hline Caucasian Entomological Bulletin & - & $\begin{array}{l}\text { http://www.ssc- } \\
\text { ras.ru/ru/journal/kavkazskii_yntomologicheskii_byulleten/ }\end{array}$ \\
\hline Entomofauna & - & http://www.insecta-web.org/MWM/index.html \\
\hline $\begin{array}{l}\text { Proceeding of the Institute of } \\
\text { Zoology }\end{array}$ & - & No web page. All 6 Printed issues were checked \\
\hline $\begin{array}{l}\text { Proceedings of the Zoological } \\
\text { Institute RAS }\end{array}$ & - & https://www.zin.ru/journals/trudyzin/eng/index.html \\
\hline
\end{tabular}

From our final database (Online Resource T2), we omitted articles reporting taxonomic revision, or nomenclatural changes of taxa based on only old museum collections (i.e. material collected before 1990) if this was not related to entirely only Georgian/Caucasian fauna. An example would be revision of some Palearctic dipteran genera, which is based on materials collected among others from Georgia before 1990. Our database also does not include studies based on fossils (paleobiology), studies dealing with animal disease, books and book chapters except those published in journals such as Zootaxa, non-indexed conference proceedings and project reports.

Each article in our final database was assigned to one of the following four categories: "Inventory" - articles that are related to only taxonomy, systematics and species inventory; "Evolutionary Biology" - articles that alone or along with the previous category dealt with phylogenetics, phylogeography or other topics of evolutionary biology; "Ecology" - articles that are related to ecological studies from single species to ecosystem levels; and "Conservation" - articles with clear emphasis on faunal conservation science.

In addition, we extracted some other information from each article including: the nationality of authors (Georgian/non-Georgian), authors' institution (including all co-authors), number of new species described, number of new species records, number of species (if summarized as a check list or simple counts) for respective taxa, and the higher level taxonomic identity (orders and phyla) of studied taxa. Checklists that were published in journals with no international editorial board were considered as preliminary and were used only for approximate estimates of total known species number for respective taxa. Additionally, for some relatively well-studied taxa, check lists have never been published in article format. These include some birds, molluscs, and spiders; 
information on those species is mainly provided in authoritative taxon-specific online databases. In such cases, we used information from those databases to calculate the number of species for respective taxa (Online Resource T3). During the compilation of a total animal species list of Georgia, we classified taxa into four completeness categories. The category "Complete" includes taxa for which no or very few new country records/new species are expected (e.g., mammals); the "Near complete" category includes taxa lists that were repeatedly studied in the last 28 years and relatively good knowledge on species diversity exists; the "Incomplete" category includes taxa lists that were prepared based on only literature sources accompanied with 1-2 studies reporting new records/species, or focused on only part of the country (e.g., parasitic hymenopteran families); and the "Preliminary" category includes taxa lists published in non-indexed (non-reviewed) journals usually based on only literature review.

Finally, we evaluated the level of completeness of our article database by calculating the omission error, to consider the possibility of studies missing in our dataset (see Arbeláez-Cortés 2013). From our compiled publication list, we randomly selected 30 articles published during the last 5 years and screened all the references provided in those articles for missing data. Since no additional articles were found following this evaluation, we considered our data as complete and this issue is not further discussed.

\section{Results}

We found 789 articles related to faunal diversity of Georgia that were published since 1990 (Online Resource T2). From those, $41 \%$ (325) have been published in WoS/Scopus indexed journals. We observed a steadily increasing trend in the number of peer-reviewed articles published per year over time (Fig. 2). While 7 or fewer indexed articles per year were appearing between 1990-2000, in the last few years, this number exceeds 30/year. Overall, $50 \%$ of indexed articles have been published during the last 5 years. In contrast, the number of nonindexed articles does not increase over time. Peaks in publication of non-indexed articles occur when special volumes are released, such as the 6-volume hard-copy-only Georgian Zoological Journal - "Proceedings of The Institute of Zoology".

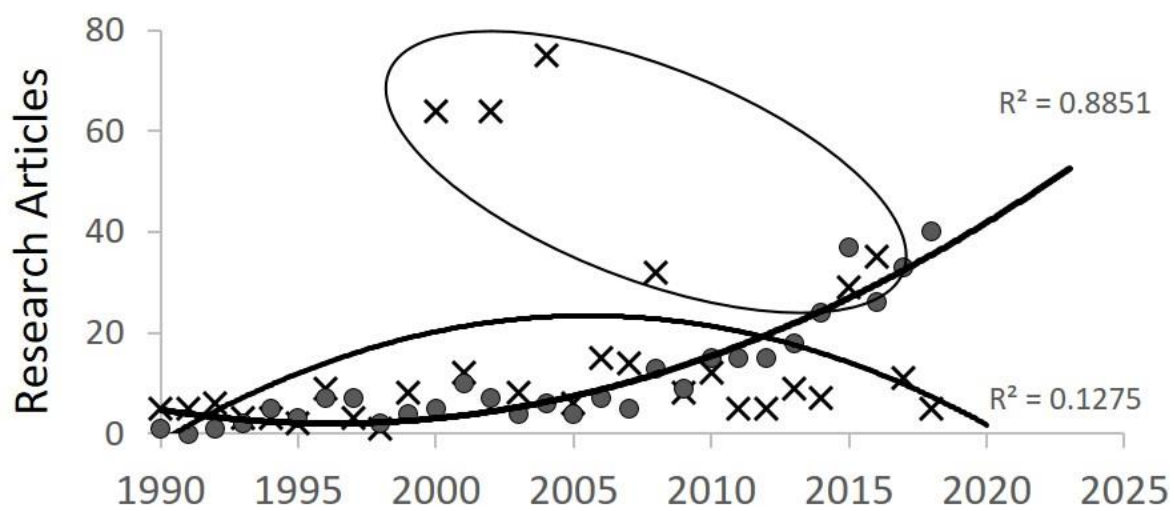

Figure 1.Plot showing the rate of publishing of research papers per year. Black dots WoS/Scopus indexed articles, Crosses - non indexed/reviewed articles. Crosses enclosed by an ellipse illustrate the six issues of "Proceedings of the Institute of Zoology" (Tbilis, Georgia) published since 1990

In our analysis, we found that the most articles fit within the "Inventory" category, focusing on description, revision, faunal inventory or check-lists of species (Fig. 3). These kind of articles accounted for $54 \%$ of all studies, $42 \%$ of which were in peer-reviewed journals. Ecological studies accounted $30 \%$ of all published articles, with 
$10 \%$ and $6 \%$ of articles were related to categories "evolution" and "conservation", respectively. In each category, indexed content was less than 50\%, except for the category "Evolution" (57\%). However, when we considered articles from only the last 10 years, indexed articles per year represent $>50 \%$ in each category and $>75 \%$ in the last two years.

Summing species list data from all categories resulted 9742 species, with information drawn from 74 summarizing (check-list) articles and 6 on-line databases (see Online Resource T3). This number does not include new species records after the publication of the respective taxa lists, though these numbers are relatively small

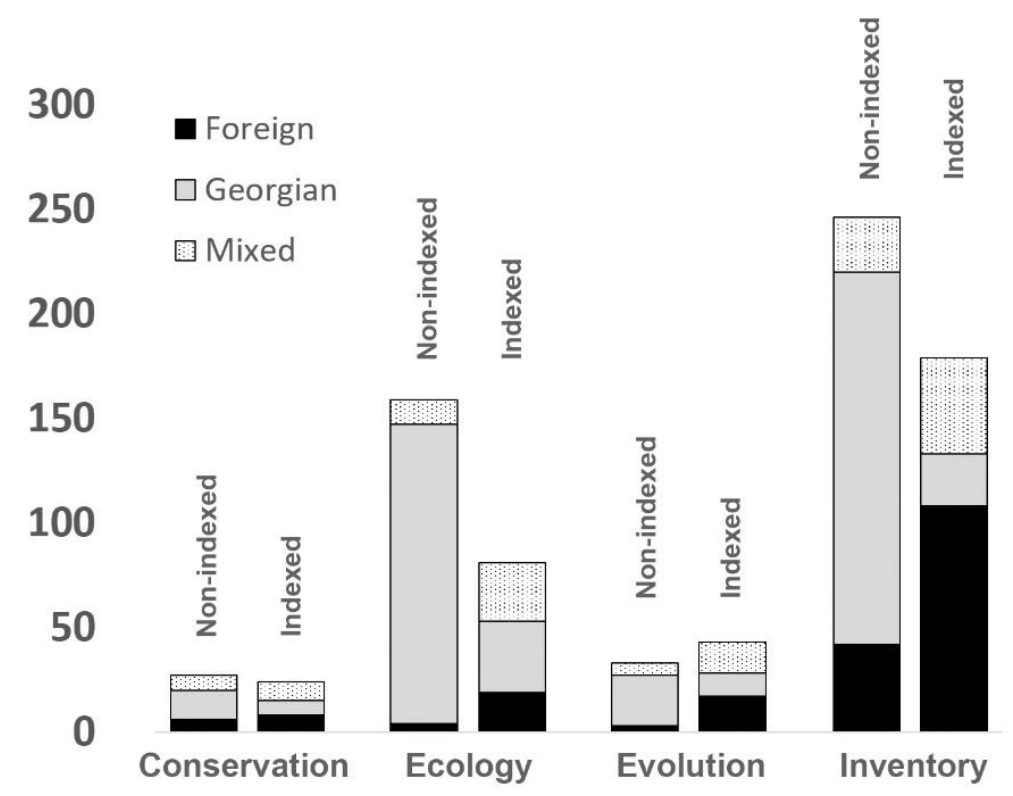

Figure 2. Distribution of research articles published between 1990-2018 by subject categories ( $x$-axis). In each category, articles were either published in peer reviewed (Indexed) or non-peer reviewed Journals (Non-indexed). Black - articles authored by non-Georgian authors only, gray - articles authored by Georgian authors only, dotted - articles with mixed authorship.

$(<100)$ and thus can have only a negligible effect on total estimate. Among the 79 taxa documented, including different taxonomic ranks from below class level to genera, 22 taxa were assigned to the categories "Complete" or "Near Complete", resulting in 3149 species (plus unpublished 12 amphibian and 61 reptile species). Apart from vertebrate taxa, this includes various arthropod taxa (families and orders) as well as a single family from Nematomorph worms. During the studied period, the most actively investigated taxa by means of published account are the suborder Oribatida (Acari) and few Hymenopteran families, aphids (Hemyptera, Aphididae) and terrestrial molluscs (Gostropoda). Though beetles (Coleoptera) were the focus of a high overall number of publications (41 in total), this number is inflated considering the diversity of coleopteran taxa; one or two papers were devoted only to selected Coleopteran families. Overall, there were 219 new species descriptions and 664 new country records published during the last 28 years (Online Resource T4). Though the trend of species discovery is increasing, the rate is relatively slow (new country records over years: Pearsons $r=0.47$; new species descriptions: Pearson's r=0.6).

Articles in our database were produced by 736 authors, of which only $34 \%$ are based in Georgia. However, the number of Georgian authors regularly contributing to biodiversity research, determined as those having $>10$ articles in the last 28 years, was 8 for indexed content and 30 for non-indexed content. Only three non-Georgian 
authors contributed 10 articles or more, with the maximum indexed content 16 articles (Online Resource T1). The distribution of authors by subject showed that the proportion of papers authored by only Georgian researchers was always high (i.e. $>50 \%$ ) in non-indexed content in each category (72\% on average). The proportion of articles produced by non-Georgian authors was highest in "Inventory" and lowest in "Ecology". Indexed collaborative articles (jointly authored by Georgian and foreign scientists together) or articles produced by non-Georgian scientists only, were always higher compared to non-indexed contents in all category (Fig. 3).

In total, 18 Georgian institutions produced one or more articles during the last 28 years (Table 2). Among them, the most productive were Ilia State University (ISU) with 98 indexed articles (55\%), followed by the Agricultural University of Georgia (AUG) with 33 (19\%) indexed articles. One notable fact with these universities is that they were formed only recently (ISU in 2006 and AUG in 2011) and the publishing rate of indexed articles is constantly increasing. In terms of non-indexed articles, these two universities are also top producers.

Works in our database were published in 183 periodicals (Online Resource T5). Additionally, 15 articles were published in conference proceedings that were indexed in the WoS database. $40.5 \%$ of all articles (322 in

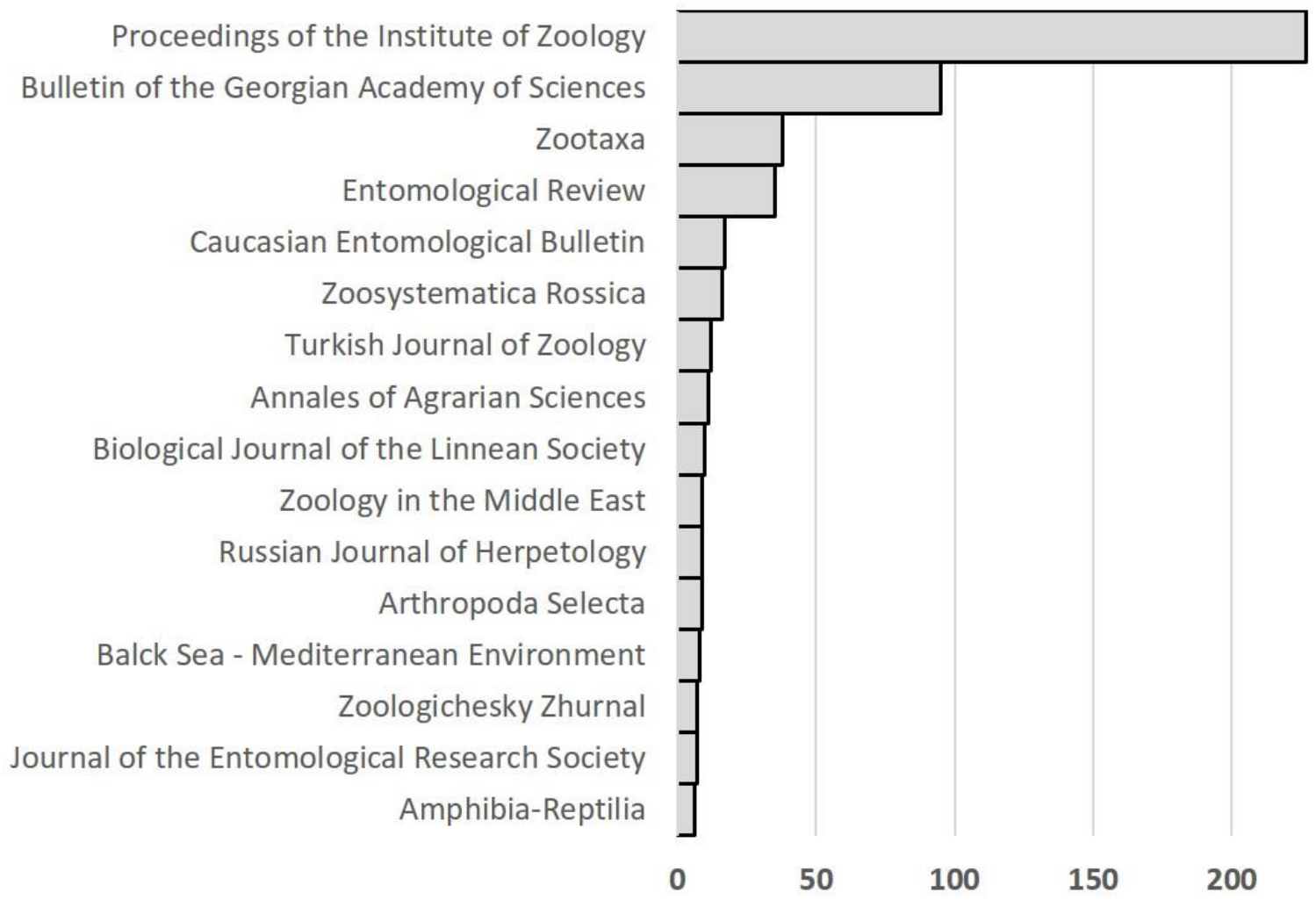

Figure 3. Periodicals that have published more than five articles on Georgian animal diversity during the last 28 years

total) have been published in two Georgian periodicals (Fig. 4), from which only 11 articles have been published in "Bulletin of the Georgian Academy of Science" after its inclusion in Scopus database. Further, 66\% of all articles have been published by 18 journals (10\%) including both strongly regional and general purpose journals, including Zootaxa and Biological Journal of the Linnean Society. 
Table 2. Number of published papers by affiliation of different Georgian institutions (including Universities, Institutes, NGOs or Govermental agencies) that participated in more than single article during the last 28 years. Asterisk indicates that the institution does not exist anymore. Note that publications jointly published by 2 or more different institutions are counted for all and accordingly the total number of papers in the table is larger than the actual number of papers.

\begin{tabular}{lll}
\hline Institution & Indexed & Not indexed \\
\hline Ilia State University & 98 & 73 \\
Agricultural University of Georgia & 33 & 13 \\
*Institute of Zoology & 20 & 254 \\
Tbilisi State University & 7 & 12 \\
${ }^{*}$ Georgian Center for Conservation of Wildlife & 4 & 6 \\
WWF & 4 & 4 \\
Sokhumi State University & 3 & 5 \\
Batumi Shota Rustaveli State University & 2 & 7 \\
NACRES & 2 & 1 \\
Abkhazia University & 1 & 2 \\
Georgian National Museum & 1 & 3 \\
National Centere for Disease Control & 1 & 1 \\
National Environmental Agency & 1 & 4 \\
Tbilisi Zoo & 1 & 1 \\
${ }^{*}$ Georgian Black Sea Fisheries and Ecology Institute & - & 4 \\
Guliashvili Institute of Forestry & - & 4 \\
Gori State Teaching Univeristy & - & 2 \\
*Kanchaveli Institute of Plant Protection & - & 12 \\
Others (institutional bodies with single articles) & 4 & 6 \\
All Georgian Institutions & $\mathbf{1 8 2}$ & $\mathbf{4 2 1}$ \\
Non Georgian institutions & $\mathbf{2 3 6}$ & $\mathbf{9 5}$ \\
\hline
\end{tabular}

\section{Discussion}

This paper represents the first effort to summarize the trends and state of the knowledge on modern faunal biodiversity research in Georgia. We have focused on the post-Soviet period of modern Georgia from 1990 to present day. To the best of our knowledge, ours is the first bibliometric analysis of its kind for faunal biodiversity research in the Caucasus region.

Although not considered in our analysis, we are aware from our own careers that during the Soviet period (1921-1990), investigation of Georgian fauna was progressing at a similar pace as in other parts of Soviet Union, as conducted by Georgian and foreign (mostly Russian) scientists. There were indeed some achievements towards a coarse understanding of species diversity and distribution at a regional scale (for instance the series of "Фауна CCCP"). However, the Soviet legacy of biodiversity knowledge is only of limited importance today because of geographic inaccuracies, taxonomic obsolescence, and limited access to voucher collections or literature sources. Therefore, information from the Soviet period is mostly useful in order to get a very rough background understanding of what might be expected in any particular taxa.

After the dissolution of Soviet Union, nearly all research reportedly slowed down as a consequence of economic and political collapse in Georgia (Papava 1995; Mitchell 2009). Our results confirm that during the first decade of Georgia's independence, biodiversity publishing was low, with $<10$ articles per year published in international peer reviewed journals (Fig. 2). With a disappearance of local funding, experimental or fieldworkbased biodiversity research completely ceased in this time. Subsequently, a torrent of funding from international 
donors started flowing to Georgia; in the case of biodiversity conservation research, most of this funding was fully dedicated to nature conservation projects, awarded as support to encourage conservation ideas or develop new units for natural resources management. This trend has continued into the present day to some extent. A noteworthy condition of the first decade of independence was an almost complete absence of young researchers. Further, biodiversity studies done by former Soviet scientists or, on rare occasions, by foreign researchers were usually based on existing literature sources and museum collections kept outside Georgia, without updating or obtaining new field data (e.g. Hausdorf 2001).

Hence, the first fifteen years of independence (period of 1990-2005) is represented by a marked gap in taxonomic and systematics research for Georgian fauna, with <10 indexed articles per year published. Instead, publication in local periodicals, most notably the Proceedings of the Institute of Zoology, was the main pathway for information sharing about Georgia in this time, even though almost all articles published there were non-peer reviewed, outdated, literature-based check lists, or systematic contributions. Despite the number of articles provided in each volume of this periodical (published 6 times since 1998), it offered little progress in our understanding of faunal diversity of Georgia. When taxonomic and distributional information was needed-for example, when designing protected areas, performing environmental impact assessment, compiling Red Lists, or obtaining research grants - the little information that existed was repeatedly employed despite inaccuracies. In addition, inaccuracies were increasing over time due to copying errors. As a consequence, at the beginning of the 21 st century, there was complete chaos in the knowledge of species diversity and distribution in most of the animal taxa in Georgia, with a few rare exceptions (large mammals, birds and amphibians, certain families of insects).

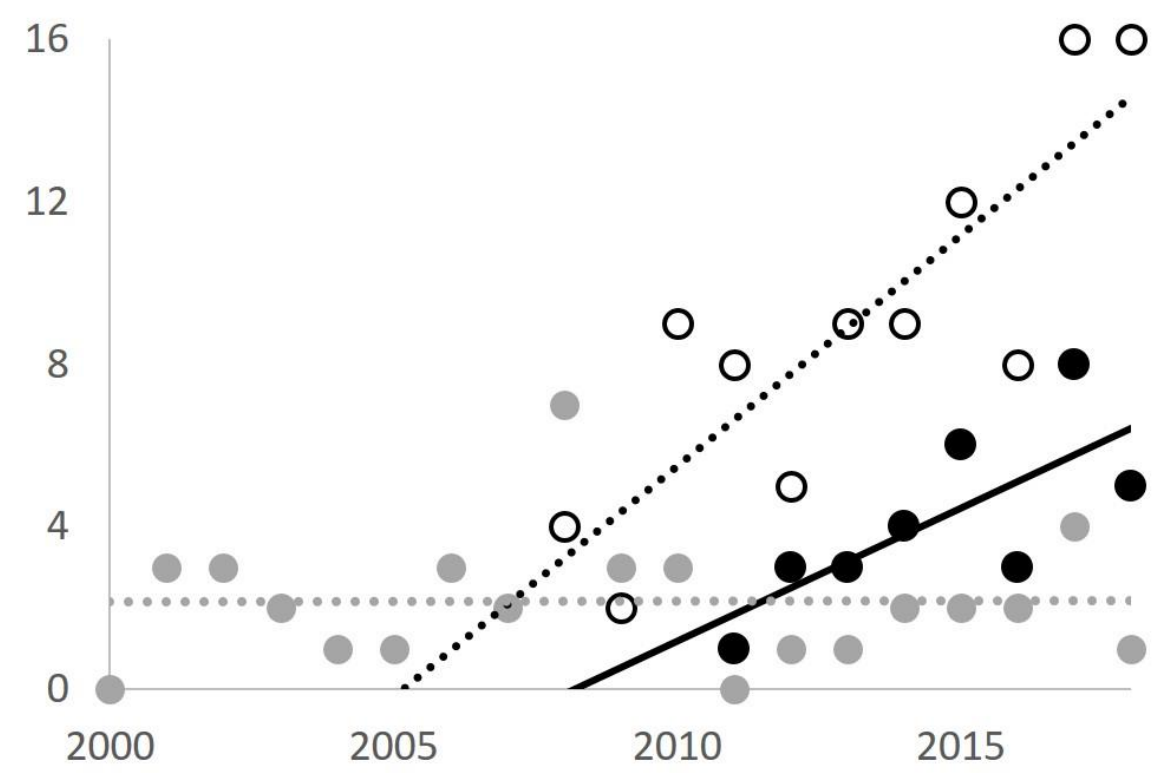

Figure 5. Publishing trends of Ilia State University (open circles; R2=0.7), Agricultural University of Georgia (black circles; $R 2=0.6)$ and all remaining indexed papers together (grey circles; $R 2<0.1$ ) since 2008. Trend lines depicting linear relationships

These trends began to change around 2007, after which the number of indexed papers has been permanently increasing, peaking in the last 4 years (Figs. 2 and 5). This increase corresponds with the establishment of Ilia State University, the first research-oriented higher education institution established in 2006, which united many biodiversity researchers in the country. Reform of the Agricultural University of Georgia in 2011 also can be linked to increased research on Georgian faunal diversity. Indeed, most of the peer-reviewed research $(>70 \%)$ 
done by Georgian researchers was associated with these two institutions. Remaining institutional bodies in Georgia, including other universities, research institutes, NGOs and governmental agencies, have contributed less than $5 \%$ of indexed articles per year during the last 8 years and that trend is constant over time (Fig. 5).

\section{How many species are there in Georgia?}

In 2007, an attempt was made to count all animal species recorded in Georgia registering 16,000 animal species (Eliava et al. 2007). Although an evaluation of the information presented by Eliava et al. (2007) is difficult due to the absence of a comprehensive literature review, this study helped with generalizations about regional species diversity. Nevertheless, this study shows likely underestimation of actual faunal species numbers for Georgia. As a point of comparison, for Bavaria (south Germany, area of 70,000 $\mathrm{km}^{2}$ ), approximately 35,000 animal species have been reported (Voith 2003), which is more than two times larger than the known species number for Georgia, a country of comparable area $\left(69,500 \mathrm{~km}^{2}\right)$ (Eliava et al. 2007). Further, Bavaria is located further north (median latitude $49^{\circ}$ ) than Georgia (median latitude $42^{\circ}$ ) and was much more affected by Pleistocene glaciations while Georgia is a plio-pleistocene refugia. A comparison of known species number between these two regions for few taxa with more or less complete inventory data from Georgia (Online Resource T6) suggests that the total number of animal species in Georgia must significantly exceed that of Bavaria.

More than 150 articles appeared during the last two decades providing taxonomic treatments and distributional data for one to several Georgian species in a traditional faunistic manner. Consequently, the number of species known for Georgia has increased, even though only a few taxa are studied actively (including three insect orders - Coleoptera (34), Hemiptera (27), Hymenoptera (26), one arachnid order - Oribatida (21) and Class Gastropoda (26)). For example, the species numbers of oribatid mites (Acari, Oribatida) - a group considered relatively well studied among other arthropods in Georgia - increased by 200 species (from 340 to 540) between 2000-2016 (Murvanidze and Darejanashvili 2000; Murvanidze and Mumladze 2016). Similar trends are notable in other groups of arthropods. For instance, a single transect study in Lagodekhi Reserve (north-eastern Georgia) resulted in hundreds of new insect species range records for the region and many new species for science (Japoshvili et al. 2016b, 2017; Kostjukov and Japoshvili 2016; Aslan et al. 2017; Japoshvili 2017; Dobosz et al. 2018; Japoshvili and Mumladze 2018; Otto and Japoshvili 2018). In other cases, a closer look at a particular arthropod taxa resulted further species descriptions. For instance, Antić and Makarov (2016) reported 36 new species of a single family Anthroleucosomatidae (Diplopoda).

During the first decades of the $21^{\text {st }}$ century, employing integrative taxonomic approaches to systematize biodiversity and accumulating accurate species distribution data has significantly increased our knowledge of biodiversity patterns and processes worldwide (Padial et al. 2010; Pante et al. 2014). Such knowledge is also believed as being critical to the development and implementation of conservation strategies (Groom et al. 2005). However, these integrative approaches are quite new for studies of Georgian biodiversity. To date, only a handful of published studies have used integrative taxonomic approaches for examining Georgian taxa (Japoshvili et al. 2013; Mumladze et al. 2013b; Barjadze et al. 2016; Tarkhnishvili et al. 2016; Walther et al. 2016; Neiber et al. 2018; Ninua et al. 2018). Even fewer published studies are available that report comprehensive and accurate (e.g., georeferenced) data on species distribution (Barjadze et al. 2015; Mumladze 2015; Golovatch et al. 2015, 2016; Schröter et al. 2015; Evsyukov et al. 2016; Murvanidze and Mumladze 2016; Seehausen et al. 2016).

A worldwide trend to develop on-line databases for primary biodiversity data has also been reflected to some 
degree in Georgia. During the last decade, several such databases have appeared (Supplementary material Table A3), and aimed to compile information on specific taxa such as spiders (Otto 2014), molluscs (Caucasian Land Snails 2012-2018), or broad-scale diversity patterns, as in the Georgian Biodiversity database (Tarkhnishvili and Chaladze 2013). The later database, which is regularly updated, includes around 14,000 animal species; this number remains lower than numbers reported by Eliava et al. (2007) and this database is still under development and revision. Improvements in the quality and comprehensiveness of this database are still challenged by limited taxonomic expertise in Georgia.

In summary, estimations of total animal biodiversity and particularly of diverse invertebrate taxa remains very difficult. Not considering species poor invertebrate taxa (such as for instance order Mantodea with just 6 species in Georgian (Battiston and Massa 2008)), species richness and distribution has been comprehensively evaluated only for soil mites (Acari, Oribatida) at a level of complete or near complete inventory (Murvanidze and Mumladze 2016). Mammals, birds, reptiles and amphibians could also be considered as fully inventoried however, these groups have not been thoroughly examined recently by means of peer reviewed articles. In addition, advanced or near complete species richness estimates are available for select taxa (Online Resource T3), totaling in 3149 species. If we consider species counts reported in other non-indexed journals (that includes mostly literature based summary of species lists frequently taxonomically unrevised), the total number of species we documented through the present examination is just over 10,000 which is or near $62 \%$ of species number reported by Eliava et al. (2007). Though this number does not encompass information on all putative species from premodern time that is not databased or revised after 1990, nevertheless, estimates are far from complete and much work is to be done to get a comprehensive understanding of actual faunal species diversity. Based on the rate of new species discovery, which we found to be $\sim 900$ species in the last 28 years, many decades of research may be needed to achieve moderately good understanding of the faunal diversity of Georgia.

\section{Patterns and process of biodiversity}

The limited extent of species diversity knowledge is also reflected in the study of bio(phylo)geographic patterns and community ecology in the Caucasus ecoregion. Several recent studies, mostly during the last ten years, are available exploring the evolutionary history of faunal species complexes in the region, limited exclusively to molluscs (Mumladze et al. 2013b; Walther et al. 2016; Neiber et al. 2018) and vertebrates (Murtskhvaladze et al. 2010; Kopaliani et al. 2014; Pilot et al. 2014; Gabelaia et al. 2015; Tarkhnishvili et al. 2016; Ninua et al. 2018). Animal community ecology and biogeography is even poorly studied in Georgia. Only a handful of articles describing community patterns or testing ecological hypotheses are available (Tarkhnishvili et al. 2010, 2012; Pokryszko et al. 2011; Murvanidze et al. 2011, 2016; Chaladze 2012; Mumladze et al. 2013a, 2015, 2017a, b, c; Chaladze et al. 2014; Murvanidze and Mumladze 2014; Gabelashvili et al. 2016; Aslan et al. 2017; Kuljanishvili et al. 2018). Overall, our understanding on Georgian (and Caucasian) animal biodiversity as a whole, community patterns at various scales, and biogeographic history is still in its infancy.

\section{Data limitations for conservation}

Biodiversity conservation is a global priority, evidenced by its inclusion in frameworks like the Sustainable Development Goals, but particularly critical in the Earth's biodiversity hotspots, such as the Caucasus region. Our review showed that conservation is the least studied subject among Georgian biodiversity-related publications 
with just $24(7 \%)$ indexed articles published during the last 28 years on this subject (Fig. 3). In the other hand, millions of USD are spent every year in the Caucasus region in order to support sustainable development and nature conservation. We suspect that limited study and information on Georgian biodiversity hampers current conservation efforts, and in some cases, biodiversity assessments likely are inaccurate. Good example is the fifth national report on biological diversity where it was reported that the Red List of Georgia contained 139 animal species and 56 wooded plant species as of 2015 (Rukhadze 2015). But the same report omitted to mention that this information was completely based on the former Soviet Georgian Red Data Book, rather than on a new evaluation of objective criteria. According to the National Biodiversity Strategy and Action Plan (NBSAP 2014), the national Red List of Georgia that was approved in 2006 has to be renewed after 10 years, in 2016. However, Georgia today has the same Red List from 2006, which is available only on a private web site (http://biodiversitygeorgia.net/). These example illustrate areas for improvement in knowledge of the biodiversity of Georgia and application of this knowledge for effective conservation planning.

Whereas there is not much experience with single species conservation in Georgia, there is an increasing network of protected areas (PA), which can be considered as a primary strategy for nature conservation (Wright and Lemons 1996). However, until now, only 10\% of Georgia's territory is under some kind of protected status; Georgia is in last place among Caucasian countries for this metric. Although we have not evaluated the effectiveness of established PAs, we are confident that the development of PAs has been most motivated by political appropriateness or "expert" knowledge, and not always with biodiversity as a central decision point. For instance, only study of the effectiveness of PAs for conservation of endemic terrestrial mollusks of Georgia showed that the existing PA network supported less than 50\% of the most important areas (Mumladze et al. 2014). Furthermore, a recent analysis of effectiveness of PAs in representing terrestrial ecosystems based on vegetation cover, concluded that it is hardly possible for Georgia to reach the minimum requirements defined by Aichi target 11 (Woodley et al. 2012) for 2020 (Mancheno et al. 2013). This in turn means that the protection of habitats and species in Georgia is currently unsatisfactory.

On the basis of deficiencies in knowledge of local biodiversity, we cannot accurately evaluate local species loss or extinction rate. Although there are increasing trends in animal biodiversity research in Georgia, conservation issues are the most scarcely represented in the literature. There are only few articles partially dealing with animal species and their habitat conservation (Gavashelishvili 2009; Mancheno et al. 2013; Mumladze et al. 2014; Gabelashvili et al. 2016; Bleyhl et al. 2017), a situation which suggests limited transmittal of existing biodiversity information to nature conservation practice.

\section{Recommendations for future research}

Data-intensive science has uncovered new opportunities in biodiversity research in recent years (Beilschmidt et al. 2017). There are at least three major developments of this kind in biodiversity study and conservation that need pursuit in Georgia. First, more studies of species' functional traits will assist with deeper understanding of patterns and process in biodiversity, and how they relate to ecosystem functioning (McGill et al. 2006). Second, DNA (meta)barcoding as a tool for rapid and effective biodiversity assessment and monitoring is increasingly used to enhance biodiversity studies (Taberlet et al. 2012; Thomsen and Willerslev 2015). And third, use of Essential Biodiversity Variables - a product of a collaborative effort of the Group on Biodiversity Observation Network (GEO BON) - could help better link different parts of the world in concerted biodiversity monitoring 
and assessment (Bruford et al. 2013). Beyond these specific frontiers in biodiversity research, adequate human resources and facilities are essential to generate and share primary biodiversity data. In Georgia - and across the Caucasus region - developments towards all of the above-listed areas are strongly limited, and there is need for expansion of facilities and people involved in biodiversity research (see also Martin et al. (2012), Amano et al. (2016) and Wetzel et al. (2018)).

Given these considerations, we suggest the following priorities to enhance faunal biodiversity research and conservation in Georgia:

1. Rapid development and implementation of a national strategy to raise awareness and interest in biodiversity research in educational institutions of all levels. A national strategy requires support from Georgian governmental institutions, under an effective monitoring scheme recognized by internationally authorized organizations. Though we are not aware of any assessment of effectiveness of existing monitoring schemes (e.g. within the framework of Convention of Biological Diversity), a national strategy is an essential tool to implement activities towards increase of environmental awareness and education.

2. Support primary biodiversity data collection by biodiversity professionals and citizen scientists. Currently, biodiversity research projects in Georgia are supported by local and international funding. However, project proposals with the aim of species inventory are usually rejected on the basis of lack of novelty or negligible impact on science. Large international conservational agencies and projects should establish specific guidelines for evaluation and incorporation of scientific information, as well as tangible outcomes, such as peer-reviewed publications guarantying either collection of new information or employing sophisticated analytical techniques. In terms of citizen science, there are few means except social networks (e.g., Facebook) that support or promote citizen science in Georgia. Even global citizen science platforms like eBird and iNaturalist receive very little use in Georgia compared to other countries and almost exclusively from visitors, rather than local enthusiasts. We see opportunities to enhance citizen science in Georgia as a way to increase primary data collection, but also to create positive attitudes of younger generations towards biodiversity (Dickinson et al. 2012; Bonney et al. 2014).

3. Support increased involvement of local scientists in international research projects. The primary responsibilities here are upon the international governmental bodies and conservation societies. Although there are many such projects (see http://www.ge.undp.org/; http://apa.gov.ge/), they are not usually related to primary biodiversity data collection or mobilization of publishable research with involvement of Georgian scientists. Recently, Ilia State University (Tbilisi) and Forschungs Museum Koenig (Bonn, German), with the support of the German government, initiated an ambitious long-term project to develop infrastructural and expert facilities in Georgia towards large-scale biodiversity documentation in the region. Projects of similar extent have the potential to support rapid accumulation of accurate primary biodiversity data at all levels of life. At the local level, the Georgian National Science Foundation (http://rustaveli.org.ge/) has a limited budget ( 7 million USD devoted to research grants in all branch of sciences in 2017). Within this limited budget, there are few research projects with the aim of primary biodiversity data collection during the last 10 years.

In summary, the status and trends of biodiversity research and conservation in Georgia might be similar in large extent to other areas of developing world. We see a strong need of development of new strategies and more efforts in all branches of environmental science in Georgia to achieve significant success in biodiversity research and conservation in this globally-relevant area.

Conflict of Interest: The authors declare that they have no conflict of interest. 


\section{Acknowledgments}

This work was supported by the Shota Rustaveli National Science Foundation under the grant \#217086. This article is dedicated to the memory of our friend and colleague Javier Maldonado-Ocampo who's efforts to document biodiversity in Colombia provided ideas for this article and inspiration for similar research in Georgia.

\section{References}

Amano T, Lamming JDL, Sutherland WJ (2016) Spatial Gaps in Global Biodiversity Information and the Role of Citizen Science. BioScience 66:393-400. https://doi.org/doi.org/10.1093/biosci/biw022

Antić D, Makarov SE (2016) The Caucasus as a major hotspot of biodiversity: Evidence from the millipede family Anthroleucosomatidae (Diplopoda, Chordeumatida). Zootaxa 4211:1-205. https://doi.org/10.11646/zootaxa.4211.1.1

Arbeláez-Cortés E (2013) Knowledge of Colombian biodiversity: published and indexed. Biodivers conserv 22:2875-2906. https://doi.org/10.1007/s10531-013-0560-y

Aslan EG, Mumladze L, Japoshvili G (2017) List of leaf beetles (Coleoptera: Chrysomelidae) from Lagodekhi reserve with new records for Transcaucasia and Georgia. Zootaxa 4277:86-98. http://dx.doi.org/10.11646/zootaxa.4277.1.6

Barjadze S, Baquero E, Soto-Adames FN et al (2016) New diagnosis for species of Plutomurus Yosii (Collembola, Tomoceridae), with descriptions of two new species from Georgian caves. Zootaxa 4126:77-96. http://dx.doi.org/10.11646/zootaxa.4126.1.3

Barjadze S, Murvanidze M, Arabuli T et al (2015) Annotated List of invertebrates of the Georgian Karst Caves. Georgian Academic Book, Tbilisi

Battiston R, Massa B (2008) The mantids of Caucasus. Acts of the roveretan academy of agiati. Class of human sciences, letters and arts 258(VIIIB):5-28

Beilschmidt C, Drönner J, Mattig M et al (2017) VAT: A Scientific Toolbox for Interactive Geodata Exploration. Datenbank-Spektrum 17:233-243. https://doi.org/10.1007/s13222-017-0266-5

Bleyhl B, Baumann M, Griffiths P et al (2017) Assessing landscape connectivity for large mammals in the Caucasus using Landsat 8 seasonal image composites. Remote Sens Environ 193:193-203. https://doi.org/10.1016/j.rse.2017.03.001

Bonney R, Shirk JL, Phillips TB et al (2014) Next steps for citizen science. Science 343:1436-1437. https://doi.org/10.1126/science.1251554

Bruford MW, Brummitt N, Butchart SHM et al (2013) Essential biodiversity variables. Science 339:277278. https://doi.org/10.1126/science.1229931

Cardoso P, Erwin TL, Borges PA et al (2011) The seven impediments in invertebrate conservation and how to overcome them. Biol Conserv 144:2647-2655. https://doi.org/10.1016/j.biocon.2011.07.024

Caucasian Land Snails (2012-2018) Universitat Hamburg. http://www.caucasus-snails.uni-hamburg.de Accessed 18 December 2017 [Temporarily unavailable]

CEPF. The Biodiversity Hotspots". https://www.cepf.net/our-work/biodiversity-hotspots. Accessed 19 December 2018

Chaladze G (2012) Climate-based model of spatial pattern of the species richness of ants in Georgia. J Insect Conserv 16:791-800. https://doi.org/10.1007/s10841-012-9464-5

Chaladze G, Otto S, Tramp S (2014) A spider diversity model for the Caucasus Ecoregion. J Insect Conserv 18:407-416. https://doi.org/10.1007/s10841-014-9649-1

Davtyan E (2014) The Role of Infrastructure in International Relations: The Case of South Caucasus. Int J Soc Sci 3:22-38

Dickinson JL, Shirk J, Bonter D et al (2012) The current state of citizen science as a tool for ecological research and public engagement. Front Ecol Evol 10:291-297. https://doi.org/10.1890/110236

Dobosz R, Japoshvili G, Krivokhatsky V et al (2018) Contributions to the knowledge of neuropterid insects (Neuropterida: Raphidioptera, Neuroptera) of Georgia (Sakartvelo). Part II. Annals of the Upper Silesian Museum in Bytom (Entomology) 26:1-20. https://doi.org/10.5281/zenodo.1147632

Edwards PJ, Abivardi C (1998) The value of biodiversity: where ecology and economy blend. Biol Conserv 83:239-246. https://doi.org/10.1016/S0006-3207(97)00141-9

Eliava I, Cholokava A, Kvavadze E et al (2007) New data on animal biodiversity of Georgia. Bulletin of the Georgian National Academy of Sciences 175:115-119.

Evsyukov A, Golovatch S, Reip HS (2016) The millipede genus Strongylosoma in the Caucasus (Diplopoda: Polydesmida, Paradoxosomatidae). Acta Societatis Zoologicae Bohemicae 80:7-16.

Fleishman E, Betrus CJ, Blair RB et al (2002) Nestedness analysis and conservation planning: the importance of place, environment, and life history across taxonomic groups. Oecologia 133:78-89. https://doi.org/10.1007/s00442-002-1003-8

Gabelaia M, Murtskhvaladze M, Tarkhnishvili D (2015) Phylogeography and morphological variation in a 
narrowly distributed Caucasian rock lizard, Darevskia mixta. Amphib Reptil 36:45-54. https://doi.org/10.1163/15685381-00002975

Gabelashvili S, Bikashvili A, Shubitidze Z et al (2016) Family level diversity and distribution of macroinvertebrates of Madatapa, Khanchali and Bughdasheni lakes in javakheti plateau (South Georgia). Proceedings of the Institute of Zoology 25:117-128

Gavashelishvili A (2009) GIS-based habitat modeling of mountain ungulate species in the Caucasus hotspot. In: Zazanashvili N, Mallon D (ed) Status and Protection of Globally Threatened species in the Caucasus. Contour Ltd, Tbilisi, pp 74-82

Golovatch S, Evsyukov A, Reip H (2016) The millipede family Polydesmidae in the Caucasus (Diplopoda: Polydesmida). Zootaxa 4085:1-51. https://doi.org./10.11646/zootaxa.4085.1.1

Golovatch S, Evsyukov A, Reip HS (2015) Colobognatha millipedes in the Caucasus (Diplopoda: Polyzoniida, Platydesmida, http://dx.doi.org/10.11646/zootaxa.3972.2.6 Siphonocryptida). Zootaxa 3972:250-266.

Groom MJ, Meffe GK, Carroll CR (2005) Principles of Conservation Biology, 3rd edn. Sinauer Assoiates, Sunderland, USA

Humphries CJ, Williams PH, Vane-Wright RI (1995) Measuring biodiversity value for conservation. Annu Rev Ecol Evol 26:93-111. https://doi.org/10.1146/annurev.es.26.110195.000521

Hausdorf B (2001) A systematic revision of Circassina from the western Caucasus region (Gastropoda: Hygromiidae). J Molluscan Stud 67:425-446. https://doi.org/10.1093/mollus/67.4.425

Japoshvili B, Bozhadze M, Gioshvili M (2016a) A review of benthic fauna biodiversity in Georgia. Ann Agrar Sci 14:7-10. https://doi.org/10.1016/j.aasci.2016.02.002

Japoshvili B, Mumladze L, Küçük F (2013) Invasive Carassius carp in Georgia: Current state of Knowladge and future perspectives. Curr Zool 59:732-739. https://doi.org/10.1093/czoolo/59.6.732

Japoshvili G (2017) New records of Encyrtids (Hymenoptera: Chalcidoidea: Encyrtidae) from Georgia, with description of seven new species. J Asia Pac Entomol 20:866-877. https://doi.org/10.1016/j.aspen.2017.06.006

Japoshvili G, Kostjukov V, Kosheleva O (2016b) New record of Tamarixia (hymenoptera: Eulophidae) from transcaucasia with some taxonomic and biogeographical notes. J Entomol Res Soc 18:113-120.

Japoshvili G, Mumladze L (2018) New species and new records of Aphelinus Dalman (Hymenoptera: Chalcidoidea: Aphelinidae) from Lagodekhi Reserve (Sakartvelo - Georgia), with diversity and distribution along an elevational gradient. Turk J Zool 43:192-202. https://doi.org/10.3906/zoo-1802-3

Japoshvili G, Salakaia M, Kirkitadze G et al (2017) List of encyrtids (Hymenoptera: Encyrtidae) from subalpine and alpine zones of lagodekhi protected areas with new records from Georgia and Transcaucasia. Turk J Zool 41:342-344. https://doi.org/10.3906/zoo-1601-67

Kopaliani N, Shakarashvili M, Gurielidze Z et al (2014) Gene flow between wolf and shepherd dog populations in Georgia (Caucasus). J Hered 105:345-353. https://doi.org/10.1093/jhered/esu014

Kostjukov VV, Japoshvili G (2016) First record of murcia-group of the genus tetrastichus (hymenoptera, eulophidae) from Transcaucasia. In: Naditka VD (ed) Biological Plant Protection as the Basis of Ecosystem Stabilization, issue 8. Krasnodar, Russia, pp 162-165

Kotze DJ, Samways MJ (1999) Support for the multi-taxa approach in biodiversity assessment, as shown by epigaeic invertebrates in an Afromontane forest archipelago. J Insect Conserv 3:125-143. https://doi.org/10.1023/A:1009660601372

Kuljanishvili T, Mumladze L, Kalous L et al (2018) Fish species composition, sex ratio and growth parameters in Saghamo Lake (Southern Georgia). Biologia 73:93-100. https://doi.org/10.2478/s11756-018-0012y

Mancheno C, Nakhutsrishvili G, Zazanashvili N (2013) A Perspective on Ecological Corridor for Maintaining Healthy Ecological Processes in the Caucasus. 5th Symposium for Research in Protected Areas. 10 to 12 June 2013, Mittersil, 5:523-526

Martin LJ, Blossey B, Ellis E (2012) Mapping where ecologists work: Biases in the global distribution of terrestrial ecological observations. Front Ecol Environ 10:195-201. https://doi.org/10.1890/110154

McGill BJ, Enquist BJ, Weiher E et al (2006) Rebuilding community ecology from functional traits. Trends Ecol Evol 21:178-185. https://doi.org/10.1016/j.tree.2006.02.002

Mitchell LA (2009) Compromising democracy: state building in Saakashvili's Georgia. Centr Asian Surv 28:171-183. https://doi.org/10.1080/02634930903034864

Mittermeier RA, Turner WR, Larsen FW et al (2011) Global Biodiversity Conservation: The Critical Role of Hotspots. In: Zachos F, Habel J (ed) Biodiversity Hotspots. Springer, Berlin, pp 3-22. https://doi.org/10.1007/978-3-642-20992-5_1

Mumladze L (2015) Species of the Genus Helix (Mollusca, Gastropoda) in Georgia. Proceedings of the Institute of Zoology 24:148-157.

Mumladze L, Asanidze Z, Walther F et al (2017a) Beyond elevation: Testing the climatic variability hypothesis vs. Rapoport's rule in vascular plant and snail species in the Caucasus. Biol J Lin Soc 121:753-763. 
https://doi.org/10.1093/biolinnean/blx027

Mumladze L, Cameron R, Pokryszko B (2014) Endemic land molluscs in Georgia (Caucasus): how well are they protected by existing reserves and national parks? J Molluscan Stud 80:67-73. https://doi.org/10.1093/mollus/eyt047

Mumladze L, Murvanidze M, Behan-Pelletier V (2013a) Compositional patterns in Holarcticpeat bog inhabiting oribatid mite (Acari: Oribatida) communities. Pedobiologia 56:41-48. https://doi.org/10.1016/j.pedobi.2012.10.001

Mumladze L, Murvanidze M, Maraun M (2017b) Patterns of oribatid mite species diversity: testing the effects of elevation, area and sampling effort. Exp Appl Acarol 72:245-262. https://doi.org/10.1007/s10493-0170153-7

Mumladze L, Murvanidze M, Maraun M et al (2015) Oribatid mite communities along an elevational gradient in Sairme gorge (Caucasus). Exp Appl Acarol 66:41-51. https://doi.org/10.1007/s10493-015-9893-4

Mumladze L, Tarkhnishvili D, Murtskhvaladze M (2013b) Systematics and evolutionary history of large endemic snails from the Caucasus (Helix buchii, and H. goderdziana) (Helicidae). Am Malacol Bull 31:225-234. https://doi.org/10.4003/006.031.0202

Mumladze L, Ulrich W, Asanidze Z et al (2017c) An inverse elevational species richness gradient of Caucasian vascular plants and Encyrtidae (Hymenoptera, Chalcidoidea). Écoscience 24:75-79. https://doi.org/10.1080/11956860.2017.1324717

Murtskhvaladze M, Gavashelishvili A, Tarkhnishvili D (2010) Geographic and genetic boundaries of brown bear (Ursus arctos) population in the Caucasus. Mol Ecol 19:1829-1841. https://doi.org/10.1111/j.1365294X.2010.04610.x

Murvanidze M, Darejanashvili S (2000) Checklist of oribatid mites (Acari, Oribatei) of Georgia. Proceedings of the institute of Zoology 20:119-138

Murvanidze M, Kvavadze E, Mumladze L et al (2011) Comparison of Earthworms (Lumbricidae) and Oribatid Mite (Acari, Oribatida) Communities in Natural and Urban Ecosystems. Vestn Zool 45:e16-e24. https://doi.org/10.2478/v10058-011-0021-6

Murvanidze M, Mumladze L (2014) Oribatid mite (Acari: Oribatida) diversity in different forest stands of Borjom-Kharagauli National Park (Georgia). Persian J Acarol 3:257-276. http://dx.doi.org/10.22073/pja.v3i4.10169

Murvanidze M, Mumladze L (2016) Annotated checklist of Georgian oribatid mites. Zootaxa 4089:1-81. https://doi.org/10.11646/zootaxa.4089.1.1

Murvanidze M, Mumladze L, Arabuli T et al (2016) Oribatida diversity in different microhabitats of Mtirala National Park. J Acarol Soc Japan 25: 35-49. https://doi.org/10.2300/acari.25.Suppl_35

Myers N, Mittermeier RA, Mittermeier CG et al (2000) Biodiversity hotspots for conservation priorities. Nature 403:853-858. https://doi.org/10.1038/35002501

NBSAP (2014) National Biodiversity Strategy and Action Plan of Georgia - 2014-2020. pp 105. https://www.cbd.int/doc/world/ge/ge-nbsap-v2-en.pdf. Accessed 18 April 2019

Neiber MT, Walther F, Hausdorf B (2018) Phylogeny and reclassification of the Caucasigenini radiation from the Caucasus region (Gastropoda, Hygromiidae). Zool Scr 47:54-62. https://doi.org/10.1111/zsc.12259

Ninua L, Tarkhnishvili D, Gvazava E (2018) Phylogeography and taxonomic status of trout and salmon from the Ponto-Caspian drainages, with inferences on European Brown Trout evolution and taxonomy. Ecol Evol 8:2645-2658. https://doi.org/10.1002/ece3.3884

Otto S (2014) Caucasian Spiders - A faunistic Database on the spiders of the Caucasus, Version 1.4. http://caucasus-spiders.info/ Accessed 12 February 2018

Otto S, Japoshvili G (2018) The spiders (Arachnida: Araneae) of the Lagodekhi Reserve, Georgia: faunistic results of a transect study and an updated checklist. Arachnology 17:375-391. doi:10.13156/arac.2017.17.8.375

Padial JM, Miralles A, De la Riva I et al (2010) The integrative future of taxonomy. Front Zool 7:16. https://doi.org/10.1186/1742-9994-7-16

Pante E, Schoelinck C, Puillandre N (2014) From integrative taxonomy to species description: one step beyond. Syst Biol 64:152-160. https://doi.org/10.1093/sysbio/syu083

Papava V (1995) The Georgian Economy: Problems of Reform. Eurasian studies 2:52-62

Pilot M, Dabrowski MJ, Hayrapetyan V et al (2014) Genetic Variability of the Grey Wolf Canis lupus in the Caucasus in Comparison with Europe and the Middle East: Distinct or Intermediary Population? PLoS ONE 9: e93828. https://doi.org/10.1371/journal.pone.0093828

Pokryszko BM, Cameron RAD, Mumladze L et al (2011) Forest snail faunas from Georgian Transcaucasia: patterns of diversity in a Pleistocene refugium. Biol J Linn Soc 102:239-250. https://doi.org/10.1111/j.10958312.2010.01575.x

Rukhadze A (2015) Georgia's Fifth National Report to the Convention on Biological Diversity. pp 76. https://www.cbd.int/doc/world/ge/ge-nr-05-en.pdf. Accessed 12 March 2019

Schmeller DS, Julliard, R, Bellingham PJ et al (2015) Towards a global terrestrial species monitoring 
program. J Nat Conserv 25:51-57. https://doi.org/10.1016/j.jnc.2015.03.003

Schröter A, Seehausen M, Kunz B et al (2015) Update of the Odonata fauna of Georgia, southern Caucasus ecoregion. Odonatologica 44:279-342

Seehausen M, Schröter A, Mumladze L et al (2016) Additional Odonata records from Georgia, southern Caucasus eco-region, with the first record of Ischnura fountaineae (Odonata: Coenagrionidae). Not odonatol 8:266-283

Stork NE (1994) Inventories of biodiversity: more than a question of numbers. In: Forey PI, Humphries CJ, Vane-Wright RI (rd) Systematics and conservation evaluation. Clarendon Press, Oxford, pp 81-100

Taberlet P, Coissac E, Pompanon F et al (2012) Towards next-generation biodiversity assessment using DNA metabarcoding. Mol Ecol 21:2045-2050. https://doi.org/10.1111/j.1365-294X.2012.05470.x.

Tarkhnishvili D, Chaladze G (2013) Georgian biodiversity database. http://www.biodiversity-georgia.net/ Accessed 11 March 2018

Tarkhnishvili D, Gabelaia M, Mumladze L et al (2016) Mitochondrial phylogeny of the Darevskia saxicola complex: two highly deviant evolutionary lineages from the easternmost part of the range. Herpetol J 26:175-182

Tarkhnishvili D, Gavashelishvili A, Avaliani A et al (2010) Unisexual rock lizard might be outcompeting its bisexual progenitors in the Caucasus. Biol J Linn Soc 101:447-460. https://doi.org/10.1111/j.10958312.2010.01498.x

Tarkhnishvili, D., Gavashelishvili, A., Mumladze, L., 2012. Palaeoclimatic models help to understand current distribution of Caucasian forest species. Biol J Linn Soc 105:231-248. https://doi.org/10.1111/j.10958312.2011.01788.x

Tarkhnishvili D, Murtskhvaladze M, Gavashelishvili A (2013) Speciation in Caucasian lizards: Climatic dissimilarity of the habitats is more important than isolation time. Biol Journal of the Linnean Society. 109, 876892. https://doi.org/10.1111/bij.12092.

Thomsen PF, Willerslev E (2015) Environmental DNA-an emerging tool in conservation for monitoring past and present biodiversity. Biol Conserv 183:4-18. https://doi.org/10.1016/j.biocon.2014.11.019

Voith J (2003) Grundlagen und Bilanzen zur Roten Liste gefährdeter Tiere Deutschlands. Schriftenreihe Bayerisches Landesamt für Umweltschutz 116:11- 24

Walther F, Neiber MT, Hausdorf B (2016) Systematic revision and molecular phylogeny of the land snail genus Fruticocampylaea (Gastropoda: Hygromiidae) from the Caucasus region. Syst Biodiv 2000:1-23. https://doi.org/10.1080/14772000.2015.1100691

Wetzel FT, Bingham HC, Groom Q et al (2018) Unlocking biodiversity data: Prioritization and filling the gaps in biodiversity observation data in Europe. Biol Conserv 221:78-85. https://doi.org/10.1016/j.biocon.2017.12.024

Woodley S, Bertzky B, Crawhall N (2012) Meeting Aichi Target 11: what does success look like for protected area systems? Parks 18:23-37

Wright RG, Lemons J (1996) National Parks and Protected Areas: Their Role in Environmental Protection. Blackwell Science Ltd, Cambridge, UK 